Article

\title{
Extracellular Vesicles Secreted by Glioma Stem Cells Are Involved in Radiation Resistance and Glioma Progression
}

\author{
Chenkai Ma ${ }^{1,+} \mathbb{D}$, Hong P. T. Nguyen ${ }^{1,+}{ }^{\text {, Jordan J. Jones }}{ }^{1,2}$, Stanley S. Stylli ${ }^{1,2} \mathbb{D}$, Clarissa A. Whitehead ${ }^{1}$, \\ Lucy Paradiso $^{1}$, Rodney B. Luwor ${ }^{1}$ D, Zammam Areeb ${ }^{1}$, Eric Hanssen ${ }^{3}$ (D), Ellie Cho ${ }^{4}$, Ulrich Putz ${ }^{5}$, \\ Andrew H. Kaye 1,2,6 and Andrew P. Morokoff 1,2,*(D)
}

Citation: Ma, C.; Nguyen, H.P.T.; Jones, J.J.; Stylli, S.S.; Whitehead,

C.A.; Paradiso, L.; Luwor, R.B.;

Areeb, Z.; Hanssen, E.; Cho, E.; et al. Extracellular Vesicles Secreted by Glioma Stem Cells Are Involved in Radiation Resistance and Glioma

Progression. Int. J. Mol. Sci. 2022, 23, 2770. https://doi.org/10.3390/ ijms 23052770

Academic Editors: Ssang-Goo Cho and Ahmed Abdal Dayem

Received: 2 February 2022 Accepted: 26 February 2022 Published: 2 March 2022

Publisher's Note: MDPI stays neutral with regard to jurisdictional claims in published maps and institutional affiliations.

Copyright: (C) 2022 by the authors. Licensee MDPI, Basel, Switzerland. This article is an open access article distributed under the terms and conditions of the Creative Commons Attribution (CC BY) license (https:// creativecommons.org/licenses/by/ $4.0 /)$.
1 Department of Surgery, The University of Melbourne, Melbourne, VIC 3052, Australia; chenkaim@student.unimelb.edu.au (C.M.); hong.nguyen1@unimelb.edu.au (H.P.T.N.); jones.jordanj@gmail.com (J.J.J.); sstylli@unimelb.edu.au (S.S.S.); cwhitehead@student.unimelb.edu.au (C.A.W.); lucialp@unimelb.edu.au (L.P.); rluwor@unimelb.edu.au (R.B.L.); z.areeb@student.unimelb.edu.au (Z.A.); andrewk@hadassah.org.il (A.H.K.)

2 Department of Neurosurgery, The Royal Melbourne Hospital, Melbourne, VIC 3052, Australia

3 Bio21 Ian Holmes Imaging Center, Department of Biochemistry and Pharmacology, Bio21 Institute, The University of Melbourne, Melbourne, VIC 3052, Australia; ehanssen@unimelb.edu.au

4 Biological Optical Microscopy Platform, The University of Melbourne, Grattan Street, Melbourne, VIC 3010, Australia; ellie.cho@unimelb.edu.au

5 The Florey Institute of Neuroscience, Royal Parade, Melbourne, VIC 3052, Australia; ulrich.putz@florey.edu.au

6 Department of Neurosurgery, Hadassah Hebrew University Hospital, Jerusalem 91120, Israel

* Correspondence: morokoff@unimelb.edu.au; Tel.: +61-3-9035-8586; Fax: +61-3-9347-6488

+ These authors contributed equally to this work.

\begin{abstract}
Glioblastoma is the most aggressive brain tumour with short survival, partly due to resistance to conventional therapy. Glioma stem cells (GSC) are likely to be involved in treatment resistance, by releasing extracellular vesicles (EVs) containing specific molecular cargoes. Here, we studied the EVs secreted by glioma stem cells (GSC-EVs) and their effects on radiation resistance and glioma progression. EVs were isolated from 3 GSCs by serial centrifugation. NanoSight measurement, cryo-electron microscopy and live imaging were used to study the EVs size, morphology and uptake, respectively. The non-GSC glioma cell lines LN229 and U118 were utilised as a recipient cell model. Wound healing assays were performed to detect cell migration. Colony formation, cell viability and invadopodium assays were conducted to detect cell survival of irradiated recipient cells and cell invasion post GSC-EV treatment. NanoString miRNA global profiling was used to select for the GSC-EVs' specific miRNAs. All three GSC cell lines secreted different amounts of EVs, and all expressed consistent levels of CD9 but different level of Alix, TSG101 and CD81. EVs were taken up by both LN229 and U118 recipient cells. In the presence of GSC-EVs, these recipient cells survived radiation exposure and initiated colony formation. After GSC-EVs exposure, LN229 and U118 cells exhibited an invasive phenotype, as indicated by an increase in cell migration. We also identified 25 highly expressed miRNAs in the GSC-EVs examined, and 8 of these miRNAs can target PTEN. It is likely that GSC-EVs and their specific miRNAs induced the phenotypic changes in the recipient cells due to the activation of the PTEN/Akt pathway. This study demonstrated that GSC-EVs have the potential to induce radiation resistance and modulate the tumour microenvironment to promote glioma progression. Future therapeutic studies should be designed to interfere with these GSC-EVs and their specific miRNAs.
\end{abstract}

Keywords: glioblastomas; exosomes; EVs; stem cells; glioma stem cells; miRNAs; PTEN; profiling

\section{Introduction}

Glioblastoma is the most common and aggressive type of brain cancer with poor median survival of around one year. Despite maximal safe surgical resection and a combi- 
nation of radiotherapy and chemotherapy [1,2], tumour recurrence is almost always seen, probably due to tumour heterogeneity both at a phenotypic and a molecular level [3]. The prognosis remains poor, despite a gross total resection at the first and at the second surgery (recurrence); however, overall survival is better in patients who had second surgery with local recurrence compared to non-local recurrence [4], as well as in those with a combination of bevacizumab and fractionated stereotactic radiotherapy (FSRT) treatment [5].

A small subpopulation of stem-like cancer cells (glioma stem cells, GSCs) is thought to be associated with resistance and subsequent repopulation of glioma cells post treatment [6-8]. The plasticity of differentiation or trans-differentiation of GSCs is regarded as one of the key drivers of recurrence $[9,10]$. However, the mechanisms of how GSCs facilitate their non-GSC glioma cells to progress are not fully elucidated [11].

Intercellular communication is emerging as an important feature of cancer and its surrounding microenvironment [12]. This communication is likely to be mediated by nanosize extracellular vesicles (EVs) and smaller vesicles of 30-100 nm called exosomes [13,14]. Several studies have demonstrated that exosomes contain specific DNA, RNA, miRNA and proteins that can cause changes in gene expression in recipient cells [15-17]. EV-mediated intra-tumour communication from stem cells to non-stem cells may also serve to promote a more aggressive cancer phenotype [18]. Glioma-derived EVs are also known to play a critical role in immune responses $[19,20]$, stimulation of angiogenesis in surrounding cells under hypoxic conditions [21] and transfer of a resistance phenotype [22-27]. In addition, a recent co-culture study of both proneural and mesenchymal phenotypes has demonstrated that EVs were able to modulate and regulate intercellular communication within the spheroid population in vitro.

Here, we isolated EVs directly from patient-derived glioma stem cells and studied their miRNA cargo and functional effects on the non-GSC glioma cells (LN229 and U118). We showed that GSC-EVs can increase migration, as well as transfer radio-resistance related cargo to recipient cells, possibly via secreting various miRNAs. However, the exact mechanism of how GSC-EVs regulate the glioma cell population and the microenvironment needs to be fully elucidated.

\section{Results and Discussion}

\subsection{Exosomes Characterisation and Internalisation}

Glioma stem cells (GSCs) derived from three patients (Supplementary Figure S1A), grown as gliomaspheres, were firstly confirmed with the presence of neuronal and stem cell markers (Nestin, GFAP, Oct3/4 and Sox2) prior to isolation of EVs. All three GSC cell lines (MU004, MU020, MU039) expressed stem cells markers, but non-GSC cell lines (LN229 and U118) did not (Supplementary Figure S1B).

Exosomes/EVs (30-150 nm, mode size $106 \pm 4.7 \mathrm{~nm}$ ) with round and membranous cup-shaped morphology were secreted by glioma stem cells, as characterised byusing a cryo-transmission electron microscope and NanoSight distribution (Figure 1A,B). GSC-EV concentrations ranged from $2.1 \times 10^{8}$ particles $/ \mathrm{mL}$ to $4.8 \times 10^{8}$ particles $/ \mathrm{mL}$ and were positive for the exosomal markers Alix, TSG101, CD9 and CD81 (Figure 1C). The CD9 expression level was seen to be consistent in EVs of all three GSC lines, while the expression level varied in other markers (Alix, TSG101 and CD81). This is in agreement with other studies [28,29]. All three GSC cell lines produced different amounts of EVs (Figure 1D), possibly reflecting the heterogeneity of the parental tumour cells. Since MU004, MU020 and MU039 belong to proneural, mesenchymal and a mixture of proneural and mesenchymal subtypes, respectively, [11,30], it is likely that the EVs content recapitulates their molecular subtype. MU020 has mesenchymal features [11], indicating that mesenchymal-like GSCs are likely to secret more EVs to modulate the surrounding bulk tumour cells. After characterisation of the GSC-EVs, we then tested whether these GSC-EVs could be taken up by the recipient cells. GSC-EVs could be taken up by recipient cells (LN229 or U118) within $16 \mathrm{~h}$ and were transferred to the daughter cells during cell division (Figure 1E and Supplementary Video S1). We also investigated the GSC-EVs storage conditions (fresh or 
$-20^{\circ} \mathrm{C}$ storage) and found that they retained their membrane structure and morphology, and that storage did not affect their functions to induce colony formation and cellular migration in LN229 recipient cells (Figure S2A,B).

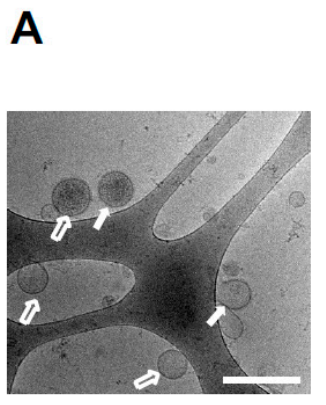

E

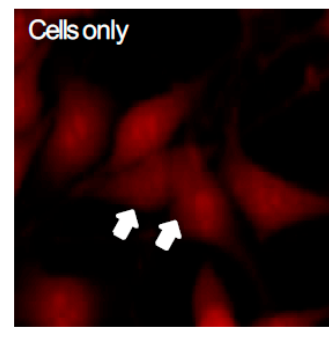

B
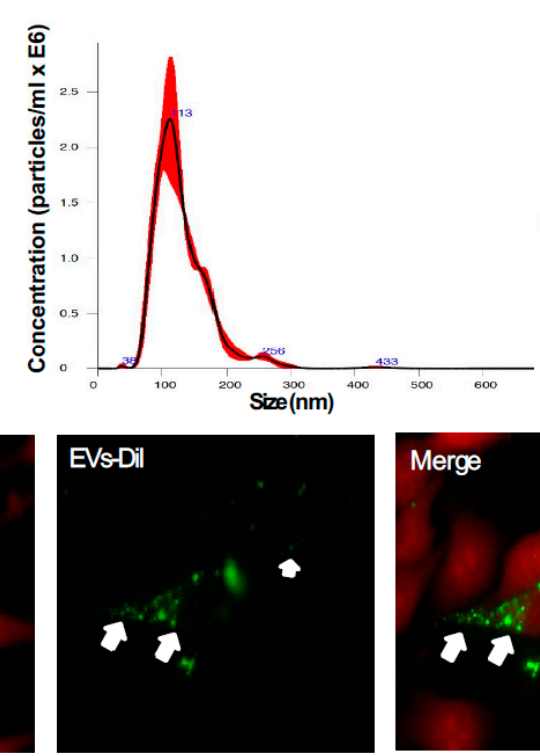
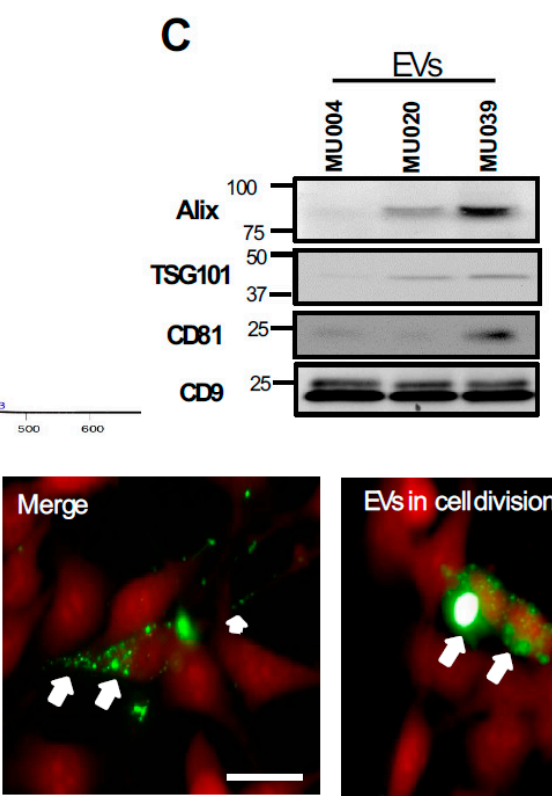

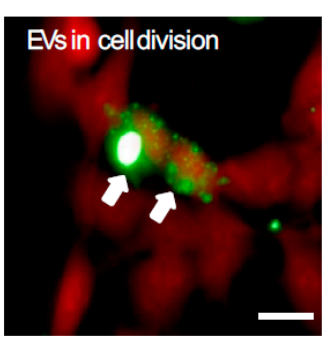

D
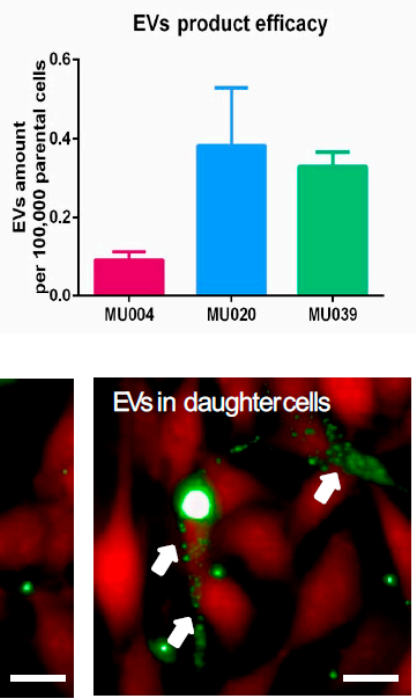

Figure 1. Characteristics of GSC-EVs. (A) Cryo-electron microscopy showing round, cup-shaped EVs (GSCs-EVs, white arrows) post differential centrifugation. Scale bar: $200 \mathrm{~nm}$. (B) NanoSight tracking analysis of concentration and size distribution of GSC-EVs. (C) Western blot analysis of exosomal markers (Alix, TSG101, CD81, CD9) in GSC-EVs (MU004, MU020, MU039). (D) Amount of EV production by GSC-EVs. (E) Representative images of GSC-EVs uptake and EVs presence in cell division and daughter cells. Red: recipient cell only; green: DiI-labelled EVs. Scale bar 200 um.

\subsection{GSC-EVs Enhance Radiation Resistance in Glioma Cells}

To test whether GSC-EVs could enhance the radiation resistance of recipient cells, we performed irradiation of recipient cells $6 \mathrm{~h}$ prior to GSC-EVs addition, followed by a colony formation assay. All the EVs derived from the three GSC lines could enhance the radiation resistance of LN229 and U118 recipient cells by increasing the colonies formed (Figure 2A,B). More visible colonies were observed with $2 \mathrm{~Gy}$ irradiation compared to $5 \mathrm{~Gy}$. Notably, recipient cells still survived irradiation with $5 \mathrm{~Gy}$ exposures and formed colonies in the presence of MU020 EVs. Cell viability experiments also confirmed that the presence of EVs resulted in both LN229 and U118 surviving the radiation exposure (Figure 2C,D).
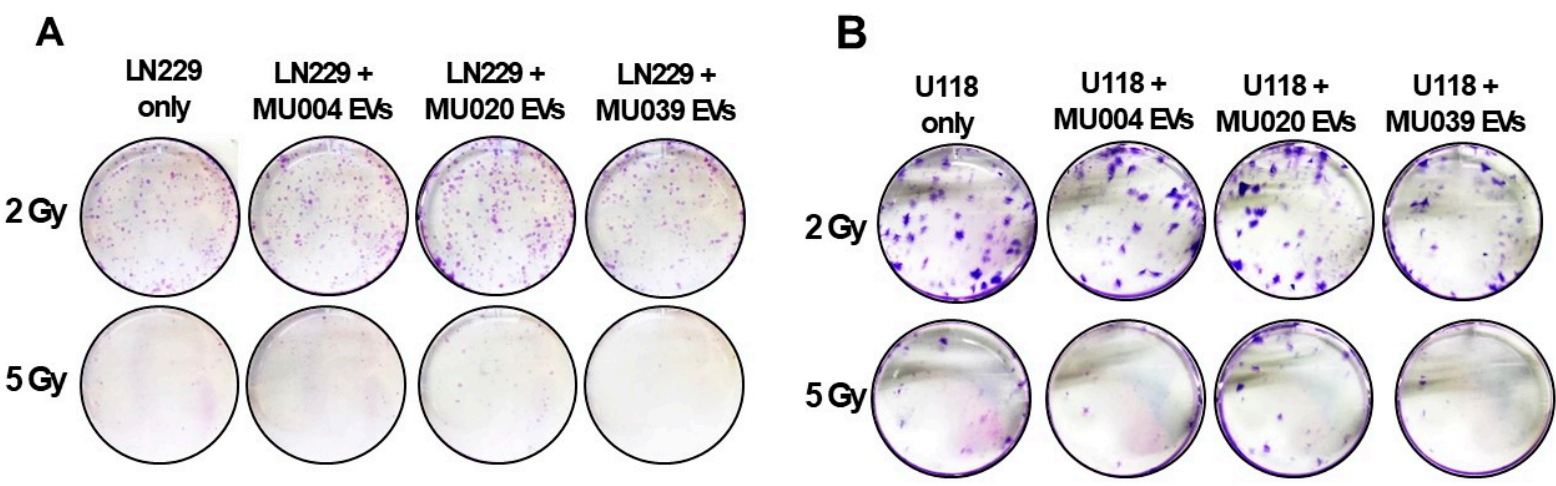

Figure 2. Cont. 
C

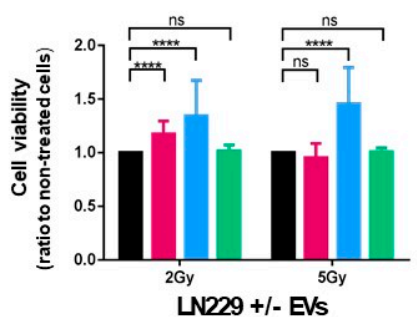

D

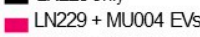

$-1 \mathrm{~N} 229+\mathrm{M}$

LN229+MU039 EVs

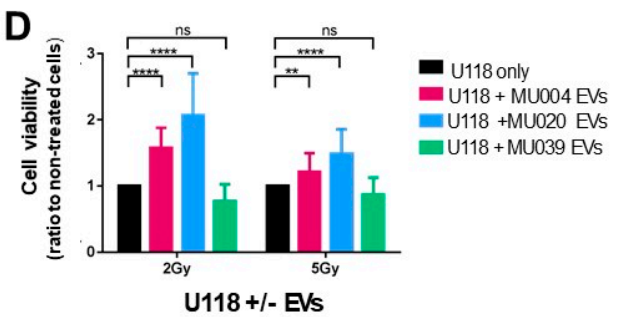

Figure 2. GSCs-EVs transfer radiation resistance. Representative images of colony formation of recipient cells (A) LN229 and (B) U118 with or without GSC-EVs after exposure to 2 Gy and 5 Gy radiation dosage. Cell viability of (C) LN229 and (D) U118 cells with and without GSC-EVs post 2 Gy and 5 Gy radiation. Significance: ns-not significant; ${ }^{* *} p \leq 0.01 ;{ }^{* * *} p \leq 0.0001$.

\subsection{GSC-Derived Exosomes Enhanced Tumour Cell Migration and Spreading}

Both LN229 and U118 cells migrated faster in the presence of GSC-EVs (Figure 3A,B), with U118 cells migrating fastest (Figure 3B). A significant rate of migration was observed at $48 \mathrm{~h}$ but not at $24 \mathrm{~h}$ post GSC-EV treatment, in both LN229 and U118 cells, in response to MU004 EVs compared to MU020 EVs and MU039 EVs (Figure 3C,D).

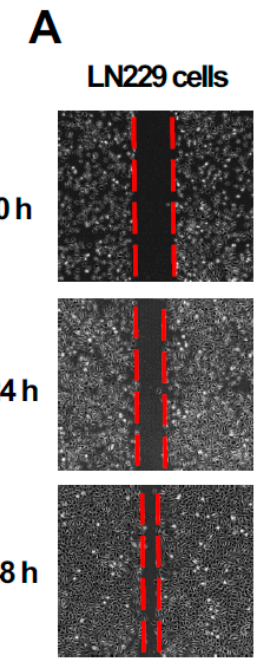

C
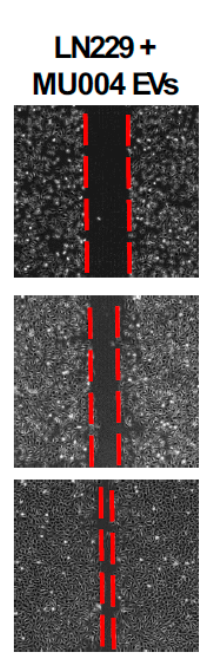

Wound healing (LN229)
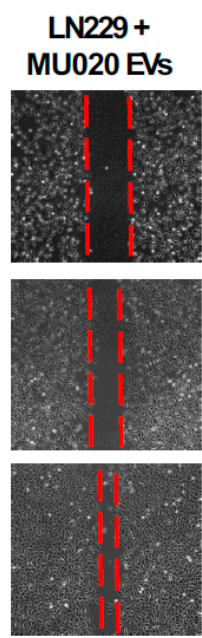

$\stackrel{\text { ns }}{\stackrel{\text { ns }}{\longrightarrow}}$

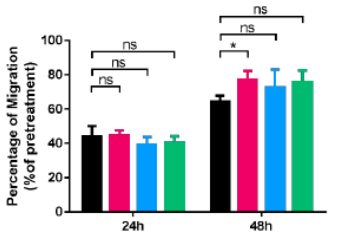

LN229only
LN229+ MU004 EVs
LN229+MU020 EVs
LN229+MU039 EVs

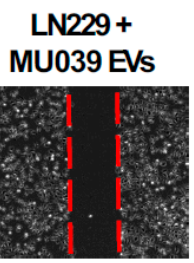

B
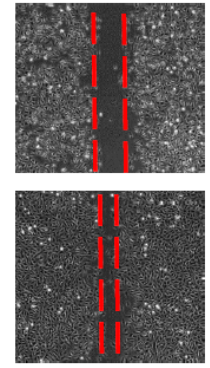

$24 \mathrm{~h}$

$\mathbf{O h}$
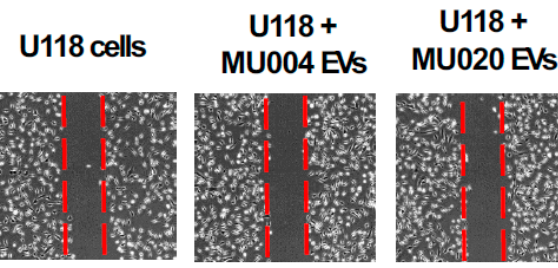

U118+
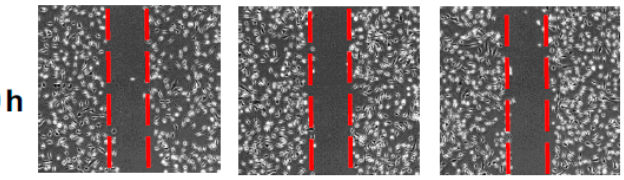

MU039 EVs
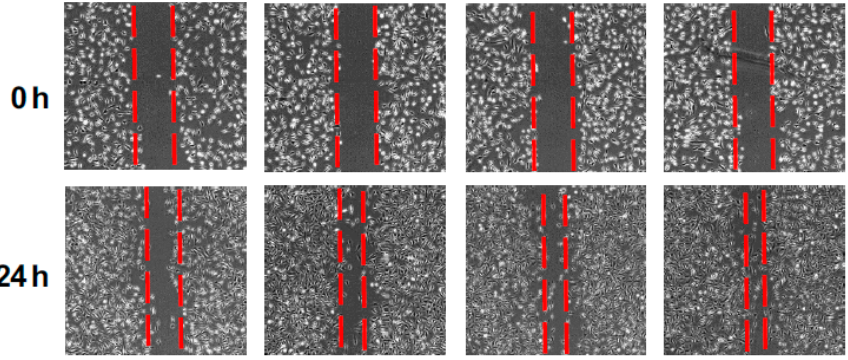

$48 \mathrm{~h}$
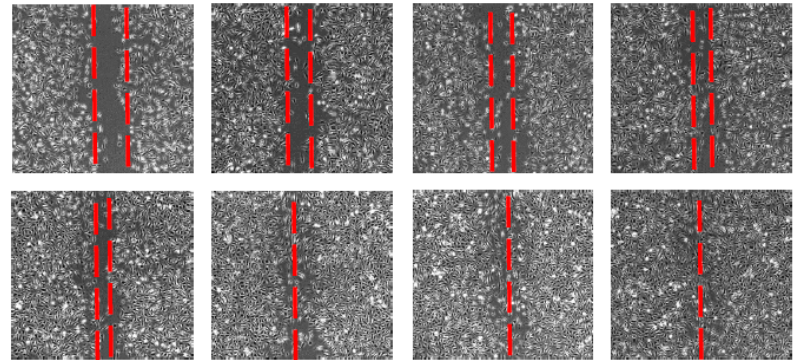

D

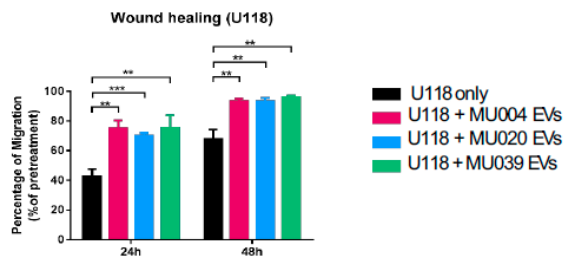

Figure 3. GSC-EVs promote cell migration. Representative phase contrast images of cell migration of (A) LN229 cells and (B) U118 cells in response to EVs from MU004, MU20 and MU39 GSCs at $24 \mathrm{~h}$ and $48 \mathrm{~h}$. Bar graphs show the percentage of migration of (C) LN229 cells and (D) U118 cells in the presence of GSC-EVs compared to untreated cells. Significance: ns-not significant; ${ }^{*} p<0.05$; ${ }^{* *} p \leq 0.01 ;{ }^{* * *} p \leq 0.001$.

\subsection{GSC-EVs Are Involved in Invadopodia and Proliferative Activity}

Glioma can be characterised by tumour cell invasion facilitated by invadopodia and associated proteases secretion [31], therefore we then examined whether GSC-EVs contained proteases. Using zymography, MMP-2 and MMP-9 bands were detected in all GSC-EVs (Figure 4A), suggesting the potential role of EVs in extracellular matrix degradation and invasion. MMP-2 expression level was higher in MU004 EVs and MU039 EVs, while MMP-9 level was more prominent in MU020 EVs (Figure 4A). Pre-incubation of the 
LN229 and U118 cells with GSC-EVs (MU004 EVs, MU020 EVs or MU039 EVs) resulted in a significant reduction in the level of invadopodia-mediated FITC-gelatin degradation compared to the untreated cells (Figure 4B,C). These data confirm our previous findings that the actin-rich invadopodia structures can facilitate matrix degradation and promote glioma cell invasion [32,33] through EV regulation [34].

A

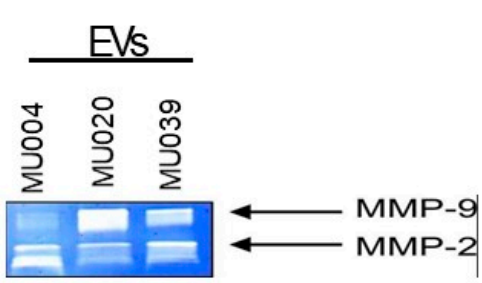

\section{C}

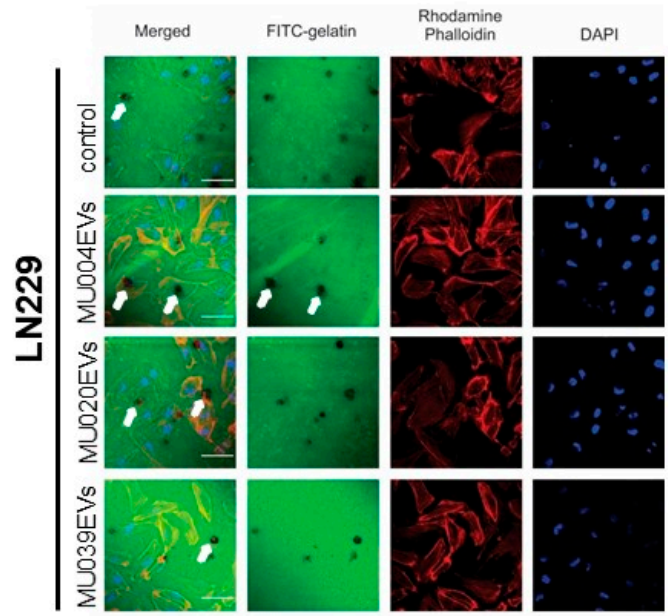

B
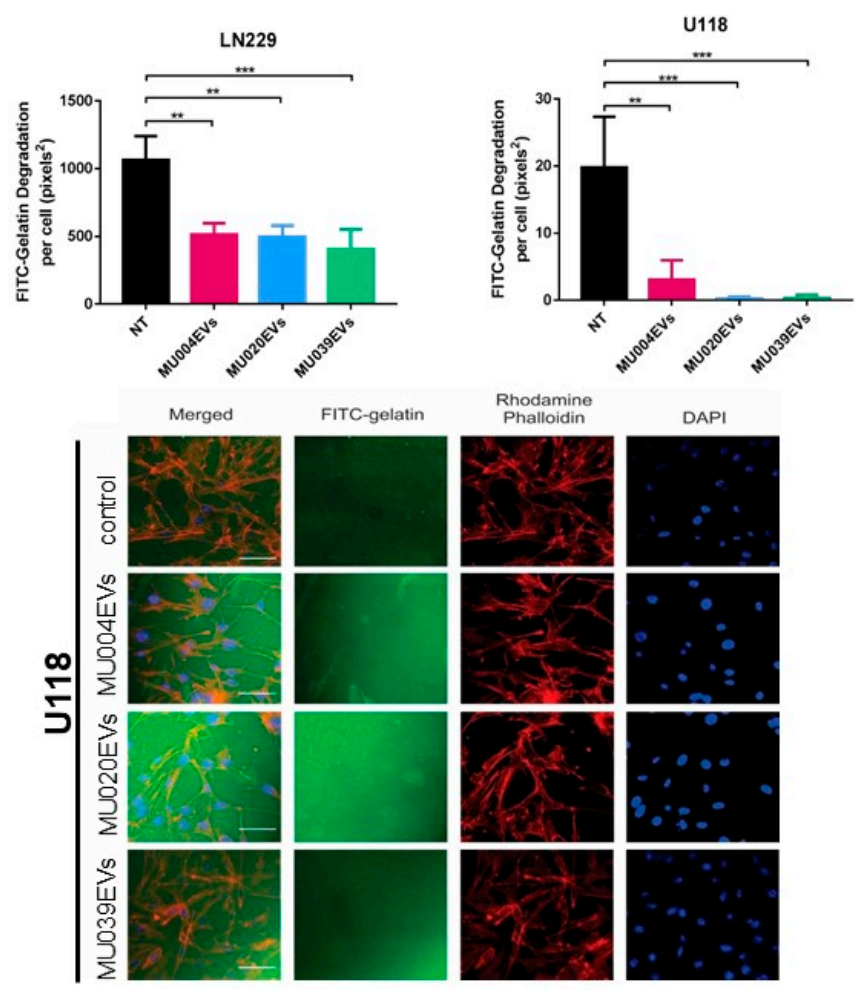

DAPI

Rhodamine
Phalloidin
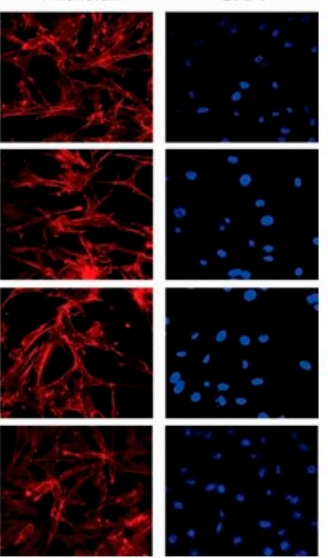

Figure 4. GSC-EVs and invadopodia activity. (A) Representative images of GSC-EVs containing invadopodia proteins MMP9 and MMP2. (B) Quantification of FITC-gelatin-coated degradation of LN229 and U118 cells after GSC-EVs exposure. Significance: ${ }^{* *} p \leq 0.05$; ${ }^{* *} p \leq 0.01$. (C) Representative confocal images of FITC-gelatin-coated degradation. White arrows: FITC-gelatin; red: rhodamine/phalloidin; blue: DAPI.

\section{5. miRNAs Cargoes in EVs Reflect GBM Phenotype}

To ascertain whether GSC-EVs contain any miRNAs that may reflect the GBM phenotype, we profiled the GSC-EVs using a NanoString miRNA assay, analysed using nSolver analysis software (v3 NanoString) and the R statistical program package. A list of 25 miRNAs were found in common within EVs derived from three GSC cell lines (Table 1). Of these, 8 miRNAs (mir320e, mir520f-3p, mir363-3p, mir144-4p, mir16-5p, mir495-3p, mir23a-3p, mir155-5p) could target the PTEN pathway when analysed and compared using TargetScan.

Further analysis was performed, and the results compared with the online database "Glioblastoma Bio Discovery Portal, GBM-BioDP". It was found that 3 miRNAs (hsamiR-142-3p, hsa-miR-551a and hsa-miR-662) out of the 25 miRNAs were associated with different subtypes of glioblastoma (Supplementary Figure S3A). Hierarchical clustering showed a high correlation of hsa-miR-142-3p with mesenchymal phenotypes of GBM [35] (Supplementary Figure S3B), while hsa-miR551a and hsa-miR612 are seen in both mesenchymal subtypes and classical subtypes. High expression of these 3 miRNAs were also associated with worse survival in the proneural subtype compared to other subtypes of GBM. 
Table 1. List of the top 25 highly expressed miRNAs in GSC-EVs.

\begin{tabular}{|c|c|c|c|c|c|c|c|}
\hline \multirow[t]{2}{*}{ Gene Name } & \multirow[t]{2}{*}{ Accession \# } & \multicolumn{3}{|c|}{ NanoString Raw Counts } & \multirow[t]{2}{*}{ Sequence } & \multirow[t]{2}{*}{ Genome Context } & \multirow[t]{2}{*}{ PTEN Position } \\
\hline & & MU004 EVs & MU020 EVs & MU039 EVs & & & \\
\hline hsa-miR-451a & MIMAT0001631 & 15,460 & 23 & 14 & $\begin{array}{l}\text { aaaccguuacca- } \\
\text { uuacugaguu }\end{array}$ & $\begin{array}{c}\text { chr17: } \\
\text { 28861369-28861440 [-] }\end{array}$ & \\
\hline${ }^{*}$ hsa-miR-320e & MIMAT0015072 & 4936 & 31 & 30 & $\begin{array}{l}\text { aaagcuggg- } \\
\text { uugagaagg }\end{array}$ & $\begin{array}{c}\text { chr19: } \\
46709293-46709345[-]\end{array}$ & $\begin{array}{c}\text { Position } 4736-4742 \\
\text { of PTEN } 3^{\prime} \text { UTR }\end{array}$ \\
\hline${ }^{*}$ hsa-miR-520f-3p & MIMAT0002830 & 726 & 1184 & 140 & $\begin{array}{l}\text { aagugcuuccu- } \\
\text { uuuagaggguu }\end{array}$ & $\begin{array}{c}\text { chr19: } \\
\text { 53682159-53682245 [+] }\end{array}$ & $\begin{array}{c}\text { Position 1149-1155 } \\
\text { of PTEN 3' UTR }\end{array}$ \\
\hline hsa-miR-873-3p & MIMAT0022717 & 162 & 154 & 123 & $\begin{array}{l}\text { ggagacugaugagu- } \\
\text { ucccggga }\end{array}$ & $\begin{array}{c}\text { chr9: } \\
28888879-28888955[-]\end{array}$ & \\
\hline hsa-miR-223-3p & MIMAT0000280 & 482 & 24 & 15 & $\begin{array}{l}\text { ugucaguuuguca- } \\
\text { aauacccca }\end{array}$ & $\begin{array}{c}\text { chrX: } \\
66018870-66018979[+]\end{array}$ & \\
\hline * hsa-miR-363-3p & MIMAT0000707 & 121 & 131 & 92 & $\begin{array}{c}\text { aauugcacggua- } \\
\text { uccaucugua }\end{array}$ & $\begin{array}{c}\text { chrX: } \\
\text { 134169378-134169452 [-] }\end{array}$ & $\begin{array}{c}\text { Position 2859-2866 } \\
\text { of PTEN 3' UTR }\end{array}$ \\
\hline * hsa-miR-144-3p & MIMAT0000436 & 390 & 21 & 16 & $\begin{array}{l}\text { uacaguauaga- } \\
\text { ugauguacu }\end{array}$ & $\begin{array}{c}\text { chr17: } \\
\text { 28861533-28861618 [-] }\end{array}$ & $\begin{array}{c}\text { Position 2917-2923 } \\
\text { of PTEN 3' UTR }\end{array}$ \\
\hline hsa-miR-598-3p & MIMAT0003266 & 117 & 112 & 75 & $\begin{array}{l}\text { uacgucaucguu- } \\
\text { gucaucguca }\end{array}$ & $\begin{array}{c}\text { chr8: } \\
\text { 11035206-11035302 [-] }\end{array}$ & \\
\hline hsa-miR-6721-5p & MIMAT0025852 & 124 & 103 & 63 & $\begin{array}{l}\text { ugggcaggggcuu- } \\
\text { auuguaggag }\end{array}$ & $\begin{array}{c}\text { chr6: } \\
\text { 32170030-32170116 [-] }\end{array}$ & \\
\hline * hsa-miR-16-5p & MIMAT0000069 & 214 & 48 & 30 & $\begin{array}{l}\text { uagcagcacgua- } \\
\text { aauauuggcg }\end{array}$ & $\begin{array}{c}\text { chr3: } \\
\text { 160404745-160404825 } \\
{[+]}\end{array}$ & $\begin{array}{c}\text { Position 4318-4325 } \\
\text { of PTEN 3' UTR }\end{array}$ \\
\hline hsa-miR-4443 & MIMAT0018961 & 79 & 91 & 56 & $\begin{array}{l}\text { uuggaggcg- } \\
\text { uggguuuu }\end{array}$ & $\begin{array}{c}\text { chr3: } \\
\text { 48196564-48196616 [+] }\end{array}$ & \\
\hline \# hsa-miR-612 & MIMAT0003280 & 67 & 65 & 83 & $\begin{array}{l}\text { gcugggcaggg- } \\
\text { cuucugagcuccuu }\end{array}$ & $\begin{array}{c}\text { chr11: } \\
\text { 65444458-65444557 [+] }\end{array}$ & \\
\hline hsa-miR-513b-5p & MIMAT0005788 & 71 & 110 & 25 & $\begin{array}{c}\text { uucacaaggaggug- } \\
\text { ucauuuau }\end{array}$ & $\begin{array}{c}\text { chrX: } \\
\text { 147199044-147199127 [-] }\end{array}$ & \\
\hline hsa-miR-1183 & MIMAT0005828 & 71 & 51 & 47 & $\begin{array}{l}\text { cacuguaggugaugg- } \\
\text { ugagagugggca }\end{array}$ & $\begin{array}{c}\text { chr7: } \\
\text { 21471058-21471146 [+] }\end{array}$ & \\
\hline${ }^{*}$ hsa-miR-495-3p & MIMAT0002817 & 60 & 75 & 41 & $\begin{array}{l}\text { aaacaaacauggu- } \\
\text { gcacuucuu }\end{array}$ & $\begin{array}{c}\text { chr14: } \\
\text { 101033755-101033836 } \\
{[+]}\end{array}$ & $\begin{array}{c}\text { Position 3221-3227 } \\
\text { of PTEN 3' UTR, } \\
\text { Position 3232-3239 } \\
\text { of PTEN 3' UTR }\end{array}$ \\
\hline${ }^{*}$ hsa-miR-23a-3p & MIMAT0000078 & 145 & 20 & 25 & $\begin{array}{l}\text { aucacauugcc- } \\
\text { agggauuucc }\end{array}$ & $\begin{array}{c}\text { chr19: } \\
13836587-13836659[-]\end{array}$ & $\begin{array}{c}\text { Position } 1608-1615 \\
\text { of PTEN } 3^{\prime} \text { UTR, } \\
\text { Position } 2279-2286 \\
\text { of PTEN 3' UTR, } \\
\text { Position } 4753-4760 \\
\text { of PTEN 3' UTR }\end{array}$ \\
\hline hsa-miR-150-5p & MIMAT0000451 & 184 & 13 & 13 & $\begin{array}{l}\text { cugguacaggc- } \\
\text { cugggggacag }\end{array}$ & $\begin{array}{c}\text { chr19: } \\
49500785-49500868[-]\end{array}$ & \\
\hline hsa-miR-761 & MIMAT0010364 & 68 & 63 & 37 & $\begin{array}{l}\text { gcagcaggguga- } \\
\text { aacugacaca }\end{array}$ & $\begin{array}{c}\text { chr1: } \\
\text { 51836344-51836402 [-] }\end{array}$ & \\
\hline hsa-miR-149-5p & MIMAT0000450 & 55 & 55 & 39 & $\begin{array}{l}\text { ucuggcuccgu- } \\
\text { gucuucacuccc }\end{array}$ & $\begin{array}{c}\text { chr2: } \\
240456001-240456089 \\
{[+]}\end{array}$ & \\
\hline hsa-miR-548ah-5p & MIMAT0018972 & 49 & 42 & 39 & $\begin{array}{l}\text { aaaagugauu- } \\
\text { gcaguguuug }\end{array}$ & $\begin{array}{c}\text { chr4: } \\
76575551-76575626[+]\end{array}$ & \\
\hline \# hsa-miR-142-3p & MIMAT0000434 & 129 & 20 & 16 & $\begin{array}{l}\text { uguaguguuuc- } \\
\text { cuacuuaaugga }\end{array}$ & $\begin{array}{l}\text { chr17: } \\
\text { 58331232-58331318 [-] }\end{array}$ & \\
\hline hsa-miR-2682-5p & MIMAT0013517 & 49 & 46 & 49 & $\begin{array}{l}\text { caggcagugacu- } \\
\text { guucagacguc }\end{array}$ & $\begin{array}{c}\text { chr1: 98045242-98045351 } \\
{[-]}\end{array}$ & \\
\hline hsa-miR-548al & MIMAT0019024 & 49 & 49 & 46 & $\begin{array}{l}\text { aacggcaaugac- } \\
\text { uuuuguacca }\end{array}$ & $\begin{array}{c}\text { chr11: } \\
\text { 74399237-74399333 [+] }\end{array}$ & \\
\hline${ }^{\#}$ hsa-miR-551a & MIMAT0003214 & 50 & 57 & 40 & $\begin{array}{l}\text { gcgacccacu- } \\
\text { cuugguuucca }\end{array}$ & $\begin{array}{c}\text { chr1: 3560695-3560790 } \\
{[-]}\end{array}$ & \\
\hline * hsa-miR-155-5p & MIMAT0000646 & 41 & 43 & 53 & $\begin{array}{l}\text { uuaaugcuaauc- } \\
\text { gugauaggggu }\end{array}$ & $\begin{array}{c}\text { chr21: } \\
25573980-25574044[+]\end{array}$ & $\begin{array}{c}\text { Position } 6323-6329 \\
\text { of PTEN 3' UTR }\end{array}$ \\
\hline
\end{tabular}

*: target PTEN. \#: Common miRNAs found in GBM Bio Discovery Portal—https://gbm-biodp.nci.nih.gov (accessed on 1 December 2021).

In this study, we demonstrated that EVs released by glioma stem cells were taken up by the recipient glioma cells and induced a phenotypic change of the glioma cells, leading them to become more migratory, invasive and radiation-resistant. These changes possibly occur via the transfer of miRNAs contents packaged within the EVs, and thus more research is underway in our laboratory to further investigate the role of these miRNAs in glioma tissue and the signalling pathways involved.

\section{Discussion}

Glioblastoma is the most aggressive form of brain cancer with little or no targeted treatment. It is known that the glioma stem cells are likely to be responsible for treatment resistance and tumour recurrence. Here, in this study, we found that GSCs secreted various 
numbers of extracellular vesicles (EVs) to modulate the microenvironment and change the tumour cell behaviour.

We studied three different GSC cell lines (MU004, MU020, MU039) derived directly from patient tissue biopsies and found that various amounts of EVs were secreted and that they expressed different exosomal markers, consistent with the published literature [36]. We found that CD9 protein was visible uniformly across all three GSC lines, which will enable us to use CD9 antibody to uniformly capture and isolate all exosomes from glioma stem cells in future studies. Our results also expand the previous conclusion that CD9 is conservatively expressed in EVs into cancer stem cells, which highlights the utility of CD9 as an EVs marker across variable cell types.

EVs secreted by tumour cells have demonstrated their ability to remodel the phenotypes of surrounding normal cells in the microenvironment, such as microglia in the brain, into a tumour-accommodating niche [19]. It is also possible that changes may occur in the genetic profiles of primary and recurrence tumours [37] and would be reflected in the EVs cargo contents, which should be further investigated. Our results highlighted that glioma cells can be manipulated by GSC-EVs to enhance progression. EVs were taken up by both LN229 and U118 recipient cells in this study and participated in cell division, suggesting that EVs are heavily involved in cell proliferation and maintenance of tumour cells within the microenvironment.

In addition, our data demonstrated that in the presence of EVs, the recipient cells can survive radiation exposure, which agrees with studies in the haematopoietic system $[38,39]$. The fact that both LN229 and U118 recipient cells treated with GSC-EVs were able to form more colonies after radiation indicates that GSCs are not only resistant to therapeutic treatment but can influence their neighbouring cells to coordinate the tumour evolution by releasing EVs [40].

It has been established that EVs mediate the transfer of histones, oncogenic species (EGFRvIII) [41], non-coding RNA (miRNA) [20] and tumour suppressors (PTEN) in glioma cells [16] and that therapeutically resistant cancer cells can transfer this resistance to sensitive cancer cells via EVs in renal cancer, breast cancer and colorectal cancer [22,24,42]. Therefore, inhibition of EV secretion or neutralising EV productions in glioma will be investigated further as a potential therapeutic target in our future studies.

We demonstrated that GSC-EVs have the ability to promote glioma cell migration, facilitate matrix degradation and promote invadopodia activity, mostly observed when GSC-EVs were added to LN229 cells. Additionally, the fact that recipient cells in this study survived radiation and formed colonies suggests that EVs play a role in cell proliferation and contribute to the "go or grow" theory of both invasion and proliferation $[43,44]$. It is possible that the mechanism of the interactions between EVs and the recipient cells can result in a final outcome where the invasive phenotype will have a low proliferative capacity, while the less invasive glioma cells are likely to be associated with high proliferative potential $[45,46]$. This inverse relationship between invasion and proliferation of glioma cells highlights the dynamic balance of cell survival when confronted with therapeutic stress [47]. It is likely that GSCs can modulate the tumour microenvironment and nearby non-GSC cells into a more proliferative or migratory phenotype by releasing EVs with specific cargo contents. This is evident in studies where GSC-EVs can modulate the activity of mesenchymal stem cells and their miRNA profiles, by mechanisms such as decreasing anti-tumour miRNAs [48] or transferring EGFRvIII molecules to cause a cellular transformation of recipient cells [41], or where EVs release the invasiveness-related proteins into the microenvironment to degrade the extracellular matrix [49]. Our data are also in agreement with a recent study by Pan et al. [44], demonstrating that glioblastomaderived EVs can promote proliferation, migration and intercellular communication in surrounding tumour cells by manipulating the PI3K-Akt-mTOR pathway. We are setting up an experiment to further investigate the effects of GSC-EVs treatment on pathways involving PTEN, PI3K and Akt. 
It is known that the cargoes in EVs, mainly miRNAs and proteins, can be selectively packaged and transported to recipient cells to modulate their functions [36]. Our NanoString data showed that there were at least 25 highly expressed miRNAs in all three GSC lines and that 8 of the 25 miRNAs (mir320e, mir520f-3p, mir363-3p, mir144-4p, mir16-5p, mir495-3p, mir23a-3p, mir155-5p) have a seed sequence to target PTEN, whilst 3 of the 25 miRNAs (mir612, mir142-3p, mir551a) were found to be common in the Glioblastoma Bio Discovery Portal of the TCGA database. This is in line with previous publications showing that miRNAs packaged within EVs can modulate the intercellular communications within the brain microenvironment [15,50-52], as well as playing a role in how the tumour responds to therapy [53]. There were many abundantly expressed miRNAs found in the EVs of T98G cells subjected to invasion [51] and serum EVs [52] involved in glioma progression [54], yet only a few miRNAs were found in common with our study, expressing at low levels (Supplementary Table S2). This is probably due to the type and heterogeneity of the cell lines studied; nevertheless, it indicates that EVs do specifically package certain miRNAs to modulate the tumour microenvironment and the intercellular communication between tumour cells and the surroundings.

Considering the potential diagnostic ability of circulating miRNAs in glioma and the relatively high proportion of miRNAs in EVs' RNA cargo [52,55-57], we are currently examining these specific miRNAs in glioma tissue and liquid biopsies to identify biomarkers for glioma progression.

We acknowledge that this study only used GSC-EVs from three patients, and we are planning to obtain more EVs from a different patient cohort including patients with recurrence tumour, to better understand the dynamic profiles of EVs and their downstream molecular effect on tumour growth and progression. Future studies should also consider manipulating EVs to selectively target glioma cell growth and progression, such as studying the effect of heparin on GSC-EVs and recipient cells, where heparin can block the transfer of EVs between cells [58].

\section{Methods}

\subsection{Ethical Approval}

All glioma stem cell lines used in this study were derived from glioblastoma tissue donated by patients who gave informed written consent. Ethical approval was obtained from the University of Melbourne (UoM) and the Royal Melbourne Hospital (RMH) Ethics Review Committees.

\subsection{Cell Culture}

Three glioma stem cell (GSC) lines were generated from primary human glioblastoma tissues collected at the time of surgery at the Royal Melbourne Hospital and maintained in our ongoing collection of samples within our Brain Tumour Tissue Bank, Department of Surgery. GSCs were cultured as gliomaspheres in serum-free medium (SFM, containing DMEM/F12 + 1\% of penicillin/streptomycin + B27 supplement, all from Life Technologies, Carlsbad, CA, USA) $+10 \mathrm{ng} / \mathrm{mL}$ epidermal growth factor $+10 \mathrm{ng} / \mathrm{mL}$ fibroblast growth factor (both from Miltenyi Biotec, Bergisch Gladbach, Germany) in a $T 75 \mathrm{~cm}^{2}$ ultralow attachment flask (Corning, New York, NY, USA) in a $10 \% \mathrm{CO}_{2}$ at $37^{\circ} \mathrm{C}$ humidified incubator. A total of 10,000 GSCs were seeded, and conditioned media were collected twice weekly for exosome collection.

The human glioma cell lines (LN229 and U118) obtained commercially from ATCC were used as recipient cells for all functional studies. These cells $\left(500 \mathrm{cells} / \mathrm{cm}^{2}\right)$ were cultured in a monolayer in DMEM supplemented with $1 \%$ of penicillin/streptomycin and $10 \%$ of foetal calf-serum (all from Life Technologies) in a $10 \% \mathrm{CO}_{2}$ at $37{ }^{\circ} \mathrm{C}$ humidified incubator.

\subsection{Exosome Isolation and Characterisation and Uptake}

GSC-derived exosomes/extracellular vesicles (GSC-EVs) isolation and characterisation were performed according to a well-established protocol $[59,60]$. Briefly, conditioned media 
(CM) samples were collected from gliomaspheres and then centrifuged at $300 \times g$ and $2000 \times g$ for $5 \mathrm{~min}$ and $10 \mathrm{~min}$, respectively. The CM samples were further centrifuged at $10,000 \times g$ for $30 \mathrm{~min}$. Supernatant was then collected and ultracentrifuged at $100,000 \times g$ for $70 \mathrm{~min}$. EV pellets were concentrated, washed with cold PBS at $100,000 \times g$ for $70 \mathrm{~min}$ and stored at $-80^{\circ} \mathrm{C}$ for downstream functional studies.

GSC-EVs uptake was performed according to a previous method with modification [61,62]. Briefly, $1 \mu \mathrm{M}$ Vybrant DiI lipophilic dye (Life Technologies) was added to GSC-EVs samples and incubated for $10 \mathrm{~min}$ at $37^{\circ} \mathrm{C}$. Excess dye was removed by washing with PBS and ultracentrifugation at $100,000 \times g$ for $70 \mathrm{~min}$ at $4{ }^{\circ} \mathrm{C}$. The DiI-labelled EVs were resuspended in $0.2 \mathrm{~mL}$ of PBS and overlaid on a $4 \mathrm{~mL} \mathrm{30 \%} \mathrm{sucrose} \mathrm{cushion}(300 \mathrm{~g} / \mathrm{L}$ of sucrose and $24 \mathrm{~g} / \mathrm{L}$ of Tris base, $\mathrm{pH} 7.4$ ), then washed by ultracentrifugation at $100,000 \times g$ for $70 \mathrm{~min}$ at $4{ }^{\circ} \mathrm{C}$. DiI-EVs were harvested at the PBS-sucrose interface and pelleted and stored at $-80^{\circ} \mathrm{C}$ for the internalisation study.

For the internalisation experiment, recipient cells (U118 or LN229) were seeded $\left(1 \times 10^{4}\right.$ /well overnight) in a CellCarrier 96-well clear black bottom plate (\#6005550, PerkinElmer, Waltham, MA, USA) and $10 \mu \mathrm{L}$ of DiI-EVs was added. The EVs internalisation was monitored and recorded every $10 \mathrm{~min}$ for $16 \mathrm{~h}$ using an Operetta high-content imaging system (PerkinElmer). A minimum of 3 fields of view for $n=3$ were recorded and data were processed using Harmony software (v4.1, PerkinElmer) and ImageJ (v1.5.1s, NIH, Bethesda, MD, USA). This experiment was performed at the Biological Optical Microscopy Platform at the University of Melbourne.

\subsection{EVs Size and Morphology Quantification}

Cryo-electron microscopy (Cryo-EM) was used to record the GSC-EVs size (40-150 nm) and morphology, as previously described [59,62]. Briefly, $3 \mu \mathrm{L}$ of freshly prepared GSC-EVs was applied to a glow-discharged carbon grid, vitrified and mounted into a Gatan cryoholder (Gatan, Inc., Pleasanton, CA, USA) and stored in cold liquid nitrogen for analysis. Images of GSC-EVs were acquired using a $300 \mathrm{kV}$ Tecnai G2 F30 system (FEI, Eindhoven, The Netherlands). A minimum of 15 fields of view were recorded per sample. The whole process was repeated at least 3 times.

Nanoparticle tracking analysis (NTA, NanoSight NS300 instrument, Malvern, UK) was used to record the size and particle concentration of GSC-EVs, using a previously described protocol $[28,29]$. A sample mixture $(100 \mu \mathrm{L}$ of GSC-EVs: $900 \mu \mathrm{L}$ of distilled water) was injected into the sample chamber using a $1 \mathrm{~mL}$ sterile syringe (BD, Franklin Lakes, NJ, USA), until the first droplet of liquid formed at the tip of the nozzle. Using the NTA software, the optimal field of view (50-100 particle/view) was set and recorded in triplicate for each sample. Data, including graphs of particle size and concentration $/ \mathrm{mL}$, were recorded and exported in csv or pdf format.

\subsection{Western Blot}

Western blotting was used to identify the exosomal protein marker, stem cell marker and PTEN/Akt-associated proteins using standard protocols. All antibodies used are listed in Supplementary Table S1. Briefly, GSC-EVs or recipient cells with or without GSCs-EVs treatment were lysed and quantified using a Pierce BCA Protein Assay Kit (Life Technologies) according to the manufacturer's instructions. Total protein $(10-50 \mu \mathrm{g})$ was mixed and incubated with a sample reducing agent and a sample buffer at $95{ }^{\circ} \mathrm{C}$ for $5 \mathrm{~min}$ and run on $4-12 \%$ Bis-Tris gels (all Life Technologies), transferred to $0.45 \mu \mathrm{m}$ polyvinylidenefluoride membranes (GE Healthcare, Rydelmere, Australia). The membrane was blocked with blocking buffer (5\% skim milk in Tris-buffered saline/Tween, TBST) for one hour on a vertical shaker and incubated with primary antibodies overnight at $4{ }^{\circ} \mathrm{C}$. The membranes were washed three times with TBST, for $15 \mathrm{~min}$ each. Secondary antibodies (goat anti-rabbit or anti-mouse IgG-HRP, 1:5000, Bio-Rad, Hercules, CA, USA) were added and incubated for one hour at room temperature, and then the wash was repeated. The signal was visualised using an ECL chemiluminescence detection kit (GE Healthcare). 


\subsection{Radiation Treatment}

Recipient cells (LN229 and U118 grown as an adherent monolayer) and GSC neurospheres were irradiated at the optimised dose (2 Gy and 5 Gy for adherent cells; 2 Gy, 4 Gy, 5 Gy and 8 Gy for GSCs neurospheres, with a cumulative exposure time of 0.80-2.50 min and a distance of 50-80 cm, using Theratronics Phoenix cobalt-60 gamma irradiator, Best Theratronics Ltd., Kanata, ON, Canada). Adherent cells $\left(1 \times 10^{3}\right.$ cells/well $)$ were seeded in a 6-well plate for $12 \mathrm{~h}$ before irradiation to ensure cell attachment, while GSCs were seeded as single cell suspensions in an ultra-low attachment plate for $18 \mathrm{~h}$ prior to irradiation.

\subsection{Cell Viability Assay}

To detect cell proliferation and cell viability, a luminescent readout assay was performed according to the manufacturer's instructions. In brief, glioma cells (LN229 and U118) with or without GSC-EV treatments were washed twice with PBS, incubated with luciferase reporter assay 1X buffer (Luminescent Cell Viability Assay, Promega, Madison, WI, USA) at room temperature for $15 \mathrm{~min}$ and read using a luminometer. Data were normalised to the non-treatment group and presented as a change in ratio.

\subsection{Clonogenic Assay}

A clonogenic assay was performed according to the previous protocol [63]. Briefly, recipient cells (LN229 and U118) were seeded in the 6-well plate at a concentration of $1 \times 10^{3}$ cells/well in triplicate, allowing for colony formation (7-10 days). Treatments (radiation alone or radiation plus GSC-EVs) were given on the next day of cell seeding and monitored. Cells were washed twice with PBS and incubated with crystal violet mixture (6.0\% glutaraldehyde and $0.5 \%$ crystal violet) at room temperature for $30 \mathrm{~min}$. Plates were washed twice with tap water, and images of colony formation were taken.

\subsection{Cell Migration/Invasion}

To examine the effect of GSC-EVs on glioma cell migration and invasion, recipient cells (LN229 and U118) were seeded $\left(1 \times 10^{4}\right.$ cells /well) into a 48 -well plate and allowed to reach $100 \%$ confluency. A scratch was made, and $10 \mu \mathrm{g}$ of GSC-EVs was added and monitored for $48 \mathrm{~h}$. The cell migration distance was captured at times $0,24 \mathrm{~h}$ and $48 \mathrm{~h}$. The percentage of cell migration was calculated as the ratio of the distance of the migrated cell over time to the distance of the initial scratch $\times 100$. All experiments were performed at least 3 times in triplicate.

\subsection{Zymography and Invadopodia Assay}

To determine the matrix metalloproteinase activity of GSC-EVs and the treated recipient cells, gelatinase zymographic measurements were made, as described [32]. Briefly, LN229 and U118 were pre-treated with GSC-EVs for 48 h, washed with PBS and cultured in serum-free medium for $24 \mathrm{~h}$ prior to collection. Conditioned media and/or GSC-EVs (MU004 EV, MU020 EV and MU039 EV) were diluted with Novex Tris-Glycine SDS sample buffer and separated by electrophoresis at $125 \mathrm{~V}$ for $1.5 \mathrm{~h}$ on Novex $10 \%$ Zymogram (gelatin) gels, followed by incubation with developing buffer for $30 \mathrm{~min}$ and incubation overnight at $37^{\circ} \mathrm{C}$, according to the manufacturer's instructions (Life Technologies). Clear and visible gelatinolytic bands and their molecular weights were identified against the loaded Precision Blue (BioRad, Hercules, CA, USA) protein markers. The gels were then scanned on a flatbed scanner for densitometric analysis using ImageJ (NIH).

To assess the invadopodia and matrix degradation ability, LN229 and U118 recipient cells were prepared by incubating GSC-EVs (MV004 EVs, MV020 EVs, MV039 EVs or untreated) for $48 \mathrm{~h}$, trypsinised and seeded at $7.5 \times 10^{4}$ cells per FITC-gelatin coated coverslip and incubated for $24 \mathrm{~h}$, as described [32,64]. Coverslips were stained with rhodamine phalloidin (dilution 1:75, Cytoskeleton Inc., Denver, CO, USA) and DAPI nuclear staining (5 $\mathrm{g} / \mathrm{mL}$, Sigma-Aldrich, St. Louis, MO, USA), as per the manufacturers' instructions. Degraded FITC-labelled gelatin was defined as a black area depleted of 
fluorescent gelatin in images acquired and analysed using a Nikon A1+ confocal microscope system equipped with a Plan Apo VC 60x DIC N2 oil immersion objective and ImageJ (NIH). A total of 10 random images per field of view were captured, and the area of degradation was calculated based on the threshold and region set for the total regions of matrix degradation in a given image field, normalised to the number of DAPI-positive nuclei.

\subsection{Exosomes miRNA Profiling and Analysis}

The miRNA profiling was performed on GSC-EVs using NanoString (NanoString Technologies, Seattle, WA, USA). Total RNA was extracted from GSC-EVs using an Exiqon miRNA extraction kit according to the manufacturer's instructions and profiled using NanoString miRNA assay profiling. Data were analysed using nSolver analysis software (v3.0, NanoString Technologies) and the R statistical package. Highly expressed miRNAs were further analysed and compared with the Glioblastoma Bio Discovery Portal (GBM-BioDP, https: / /gbm-biodp-nci-nih-gov (accessed on 1 December 2021) [65]) for glioma relevance and survival status [65]. It is acknowledged that the data compiled here on the GBM-BioDP were based on the H-miRNA_8 $\times 15 \mathrm{~K}$ platform studied by Verhaak et al. [35,65].

\subsection{Statistical Analysis}

All plots were analysed and generated using GraphPad Prism v7 (GraphPad, San Diego, CA, USA). Student's $t$-test was used to compare treatment and control groups. Where indicated, one-way or two-way ANOVA was used for multiple-group comparisons, and a post hoc test for individual comparison was then performed when differences were shown using ANOVA. Differences were considered to be statistically significant when the $p$-value was less than 0.05 . All miRNA counts were derived from the algorithm formula within the nSolver analysis software (v3.0, NanoString Technologies).

\section{Conclusions}

This study demonstrated that extracellular vesicles are secreted by glioma stem cells (GSC-EVs) to modulate the tumour microenvironment and make the tumour cells become resistant to radiation treatment. GSC-EVs contain a specific set of miRNAs and can promote glioma cell migration, invasion and proliferation, probably via the PTEN/Akt pathway. Currently, we are examining the expression of these miRNAs within the plasma and serum derived from patients, to study their effects on the activation of the PTEN/Akt pathway. Our future aims are to inhibit the GSC-EVs action and to neutralise these GSC-EVs as therapeutic targets.

Supplementary Materials: The following supporting information can be downloaded at: https: / / www.mdpi.com/article/10.3390/ijms23052770/s1.

Author Contributions: Conceptualization, H.P.T.N., C.M., U.P. and A.P.M.; Data curation, H.P.T.N., C.M., R.B.L., E.H. and E.C.; Formal analysis, H.P.T.N., C.M., S.S.S., C.A.W., E.H. and E.C.; funding acquisition, H.P.T.N., A.H.K. and A.P.M.; investigation, H.P.T.N., C.M., Z.A., L.P., R.B.L., E.C. and A.P.M.; Methodology, H.P.T.N., C.M., Z.A., S.S.S., E.H., U.P. and A.P.M.; project administration, L.P. and H.P.T.N.; resources, E.H., E.C., A.H.K. and A.P.M.; software, E.H. and E.C.; supervision, A.H.K., A.P.M. and R.B.L.; validation, H.P.T.N., C.M., J.J.J., Z.A., S.S.S. and C.A.W.; writing, H.P.T.N., C.M., S.S.S., R.B.L., J.J.J. and A.P.M. All authors have read and agreed to the published version of the manuscript.

Funding: C.M. is a recipient of the Melbourne International Research Scholarship, H.P.T.N. is the recipient of the Department of Surgery Early Career Research Seeding Grant, A.P.M. is the recipient of the Royal Melbourne Hospital Neuroscience Foundation.

Institutional Review Board Statement: The study was conducted in accordance with the Declaration of Helsinki, and approved by the University of Melbourne (UoM) and the Royal Melbourne Hospital (RMH) Ethics Review Committees (HREC 2009.114). 
Informed Consent Statement: Informed consent was obtained from all subjects involved in the study.

Data Availability Statement: All figures and data used to support the findings of this study are included within the article or can be made available through the corresponding author upon request.

Acknowledgments: The authors would like to acknowledge support from the Cure Brain Cancer Foundation, the Royal Melbourne Hospital Neuroscience Foundation (A.P. Morokoff), The University of Melbourne International Research Scholarship (C. Ma), and the Department of Surgery Early Career Research Seeding Grant (H.P.T. Nguyen). The Victorian Government is also acknowledged for infrastructure support.

Conflicts of Interest: The authors declare no conflict of interest.

\section{References}

1. Kaye, A.H.; Morokoff, A. The Continuing Evolution: Biology and Treatment of Brain Tumors. Neurosurgery 2014, 61 (Suppl S1), 100-104. [CrossRef] [PubMed]

2. $\quad$ Stupp, R.; Mason, W.P.; van den Bent, M.J.; Weller, M.; Fisher, B.; Taphoorn, M.J.B.; Belanger, K.; Brandes, A.A.; Marosi, C.; Bogdahn, U.; et al. Radiotherapy plus Concomitant and Adjuvant Temozolomide for Glioblastoma. N. Engl. J. Med. 2005, 352, 987-996. [CrossRef] [PubMed]

3. Sottoriva, A.; Spiteri, I.; Piccirillo, S.G.M.; Touloumis, A.; Collins, V.P.; Marioni, J.C.; Curtis, C.; Watts, C.; Tavaré, S. Intratumor heterogeneity in human glioblastoma reflects cancer evolutionary dynamics. Proc. Natl. Acad. Sci. USA 2013, 110, $4009-4014$. [CrossRef]

4. Pasqualetti, F.; Montemurro, N.; Desideri, I.; Loi, M.; Giannini, N.; Gadducci, G.; Malfatti, G.; Cantarella, M.; Gonnelli, A.; Montrone, S.; et al. Impact of recurrence pattern in patients undergoing a second surgery for recurrent glioblastoma. Acta Neurol. Belg. 2021, 1-6. [CrossRef] [PubMed]

5. Palmer, J.D.; Bhamidipati, D.; Song, A.; Eldredge-Hindy, H.B.; Siglin, J.; Dan, T.D.; Champ, C.E.; Zhang, I.; Bar-Ad, V.; Kim, L.; et al. Bevacizumab and re-irradiation for recurrent high grade gliomas: Does sequence matter? J. Neurooncol. 2018, 140, 623-628. [CrossRef]

6. $\quad$ Bao, S.; Wu, Q.; McLendon, R.E.; Hao, Y.; Shi, Q.; Hjelmeland, A.B.; Dewhirst, M.W.; Bigner, D.D.; Rich, J.N. Glioma stem cells promote radioresistance by preferential activation of the DNA damage response. Nature 2006, 444, 756-760. [CrossRef] [PubMed]

7. Chen, J.; Li, Y.; Yu, T.-S.; McKay, R.M.; Burns, D.K.; Kernie, S.G.; Parada, L.F. A restricted cell population propagates glioblastoma growth after chemotherapy. Nature 2012, 488, 522-526. [CrossRef]

8. $\quad$ Singh, S.K.; Clarke, I.D.; Terasaki, M.; Bonn, V.E.; Hawkins, C.; Squire, J.; Dirks, P.B. Identification of a cancer stem cell in human brain tumors. Cancer Res. 2003, 63, 5821-5828. [PubMed]

9. Zheng, H.; Ying, H.; Yan, H.; Kimmelman, A.C.; Hiller, D.J.; Chen, A.J.; Perry, S.R.; Tonon, G.; Chu, G.C.; Ding, Z.; et al. p53 and Pten control neural and glioma stem/progenitor cell renewal and differentiation. Nature 2008, 455, 1129-1133. [CrossRef] [PubMed]

10. Hu, B.; Wang, Q.; Wang, Y.A.; Hua, S.; Sauvé, C.-E.G.; Ong, D.; Lan, Z.D.; Chang, Q.; Ho, Y.W.; Monasterio, M.M.; et al. Epigenetic Activation of WNT5A Drives Glioblastoma Stem Cell Differentiation and Invasive Growth. Cell 2016, 167, 1281-1295.e18. [CrossRef] [PubMed]

11. Brown, D.V.; Filiz, G.; Daniel, P.M.; Hollande, F.; Dworkin, S.; Amiridis, S.; Kountouri, N.; Ng, W.; Morokoff, A.P.; Mantamadiotis, T. Expression of CD133 and CD44 in glioblastoma stem cells correlates with cell proliferation, phenotype stability and intra-tumor heterogeneity. PLOS ONE 2017, 12, e0172791. [CrossRef] [PubMed]

12. Santiago-Dieppa, D.R.; Steinberg, J.; Gonda, D.; Cheung, V.J.; Carter, B.S.; Chen, C.C. Extracellular vesicles as a platform for 'liquid biopsy' in glioblastoma patients. Expert. Rev. Mol. Diagn. 2014, 14, 819-825. [CrossRef] [PubMed]

13. Godlewski, J.; Krichevsky, A.M.; Johnson, M.D.; Chiocca, E.A.; Bronisz, A. Belonging to a network-Micrornas, extracellular vesicles, and the glioblastoma microenvironment. Neuro-Oncology 2015, 17, 652-662. [CrossRef]

14. Luga, V.; Wrana, J.L. Tumor-Stroma Interaction: Revealing Fibroblast-Secreted Exosomes as Potent Regulators of Wnt-Planar Cell Polarity Signaling in Cancer Metastasis. Cancer Res. 2013, 73, 6843-6847. [CrossRef]

15. Akers, J.C.; Ramakrishnan, V.; Kim, R.; Skog, J.; Nakano, I.; Pingle, S.; Kalinina, J.; Hua, W.; Kesari, S.; Mao, Y.; et al. MiR-21 in the extracellular vesicles (EVs) of cerebrospinal fluid (CSF): A platform for glioblastoma biomarker development. PLoS ONE 2013, 8, e78115. [CrossRef] [PubMed]

16. Putz, U.; Howitt, J.; Doan, A.; Goh, C.-P.; Low, L.-H.; Silke, J.; Tan, S.-S. The Tumor Suppressor PTEN Is Exported in Exosomes and Has Phosphatase Activity in Recipient Cells. Sci. Signal. 2012, 5, ra70. [CrossRef] [PubMed]

17. Li, C.C.Y.; Eaton, S.; Young, P.E.; Lee, M.; Shuttleworth, R.; Humphreys, D.; Grau, G.; Combes, V.; Bebawy, M.; Gong, J.; et al. Glioma microvesicles carry selectively packaged coding and non-coding RNAs which alter gene expression in recipient cells. RNA Biol. 2013, 10, 1333-1344. [CrossRef] 
18. Ricklefs, F.; Mineo, M.; Rooj, A.K.; Nakano, I.; Charest, A.; Weissleder, R.; Breakefield, X.O.; Chiocca, E.A.; Godlewski, J.; Bronisz, A. Extracellular Vesicles from High-Grade Glioma Exchange Diverse Pro-oncogenic Signals That Maintain Intratumoral Heterogeneity. Cancer Res. 2016, 76, 2876-2881. [CrossRef]

19. van der Vos, K.E.; Abels, E.R.; Zhang, X.; Lai, C.; Carrizosa, E.; Oakley, D.; Prabhakar, S.; Mardini, O.; Crommentuijn, M.H.W.; Skog, J.; et al. Directly visualized glioblastoma-derived extracellular vesicles transfer RNA to microglia/macrophages in the brain. Neuro-Oncology 2016, 18, 58-69. [CrossRef]

20. Skog, J.; Wurdinger, T.; van Rijn, S.; Meijer, D.H.; Gainche, L.; Sena-Esteves, M.; Curry, W.T., Jr.; Carter, B.S.; Krichevsky, A.M.; Breakefield, X.O. Glioblastoma microvesicles transport RNA and proteins that promote tumour growth and provide diagnostic biomarkers. Nat. Cell Biol. 2008, 10, 1470-1476. [CrossRef]

21. Kucharzewska, P.; Christianson, H.C.; Welch, J.E.; Svensson, K.J.; Fredlund, E.; Ringnér, M.; Mörgelin, M.; Bourseau-Guilmain, E.; Bengzon, J.; Belting, M. Exosomes reflect the hypoxic status of glioma cells and mediate hypoxia-dependent activation of vascular cells during tumor development. Proc. Natl. Acad. Sci. USA 2013, 110, 7312-7317. [CrossRef]

22. Boelens, M.C.; Wu, T.J.; Nabet, B.Y.; Xu, B.; Qiu, Y.; Yoon, T.; Azzam, D.J.; Victor, C.T.-S.; Wiemann, B.Z.; Ishwaran, H.; et al. Exosome Transfer from Stromal to Breast Cancer Cells Regulates Therapy Resistance Pathways. Cell 2014, 159, 499-513. [CrossRef]

23. Au Yeung, C.L.; Co, N.N.; Tsuruga, T.; Yeung, T.L.; Kwan, S.Y.; Leung, C.S.; Li, Y.; Lu, E.S.; Kwan, K.; Wong, K.-K.; et al. Exosomal transfer of stroma-derived miR21 confers paclitaxel resistance in ovarian cancer cells through targeting APAF1. Nat. Commun. 2016, 7, 11150. [CrossRef]

24. Qu, L.; Ding, J.; Chen, C.; Wu, Z.; Liu, B.; Gao, Y.; Chen, W.; Liu, F.; Sun, W.; Li, X.-F.; et al. Exosome-transmitted lncARSR promotes sunitinib resistance in renal cancer by acting as a competing endogenous RNA. Cancer Cell 2016, 29, 653-668. [CrossRef]

25. Yang, J.-K.; Yang, J.-P.; Tong, J.; Jing, S.-Y.; Fan, B.; Wang, F.; Sun, G.-Z.; Jiao, B.-H. Exosomal miR-221 targets DNM3 to induce tumor progression and temozolomide resistance in glioma. J. Neuro-Oncol. 2016, 131, 255-265. [CrossRef]

26. Zhang, Z.; Yin, J.; Lu, C.; Wei, Y.; Zeng, A.; You, Y. Exosomal transfer of long non-coding RNA SBF2-AS1 enhances chemoresistance to temozolomide in glioblastoma. J. Exp. Clin. Cancer Res. 2019, 38, 166. [CrossRef]

27. Yue, X.; Lan, F.; Xia, T. Hypoxic Glioma Cell-Secreted Exosomal miR-301a Activates Wnt/ $\beta$-catenin Signaling and Promotes Radiation Resistance by Targeting TCEAL7. Mol. Ther. 2019, 27, 1939-1949. [CrossRef]

28. Yoshioka, Y.; Konishi, Y.; Kosaka, N.; Katsuda, T.; Kato, T.; Ochiya, T. Comparative marker analysis of extracellular vesicles in different human cancer types. J. Extracell. Vesicles 2013, 2, 20424. [CrossRef]

29. Willms, E.; Johansson, H.J.; Mäger, I.; Lee, Y.; Blomberg, K.E.M.; Sadik, M.; Alaarg, A.; Smith, C.I.E.; Lehtiö, J.; El Andaloussi, S.; et al. Cells release subpopulations of exosomes with distinct molecular and biological properties. Sci. Rep. 2016, 6, 22519. [CrossRef]

30. Brown, D.V.; Daniel, P.M.; D'Abaco, G.M.; Gogos, A.; Ng, W.; Morokoff, A.; Mantamadiotis, T. Coexpression analysis of CD133 and CD44 identifies Proneural and Mesenchymal subtypes of glioblastoma multiforme. Oncotarget 2015, 6, 6267-6280. [CrossRef]

31. Whitehead, C.; Nguyen, H.P.T.; Morokoff, A.; Luwor, R.; Paradiso, L.; Kaye, A.H.; Mantamadiotis, T.; Stylli, S.S. Inhibition of Radiation and Temozolomide-Induced Invadopodia Activity in Glioma Cells Using FDA-Approved Drugs. Transl. Oncol. 2018, 11, 1406-1418. [CrossRef]

32. Mao, L.; Whitehead, C.; Paradiso, L.; Kaye, A.H.; Morokoff, A.; Luwor, R.; Stylli, S.S. Enhancement of invadopodia activity in glioma cells by sublethal doses of irradiation and temozolomide. J. Neurosurg. 2017, 129, 598-610. [CrossRef]

33. Stylli, S.S.; Kaye, A.H.; Lock, P. Invadopodia: At the cutting edge of tumour invasion. J. Clin. Neurosci. 2008, 15, 725-737. [CrossRef]

34. Gourlay, J.; Morokoff, A.; Luwor, R.; Zhu, H.-J.; Kaye, A.H.; Stylli, S.S. The emergent role of exosomes in glioma. J. Clin. Neurosci. 2017, 35, 13-23. [CrossRef]

35. Verhaak, R.G.W.; Hoadley, K.A.; Purdom, E.; Wang, V.; Qi, Y.; Wilkerson, M.D.; Miller, C.R.; Ding, L.; Golub, T.; Mesirov, J.P.; et al. Integrated Genomic Analysis Identifies Clinically Relevant Subtypes of Glioblastoma Characterized by Abnormalities in PDGFRA, IDH1, EGFR, and NF1. Cancer Cell 2010, 17, 98-110. [CrossRef]

36. Yanez-Mo, M.; Siljander, P.R.; Andreu, Z.; Zavec, A.B.; Borras, F.E.; Buzas, E.I.; Buzas, K.; Casal, E.; Cappello, F.; Carvalho, J.; et al. Biological properties of extracellular vesicles and their physiological functions. J. Extracell. Vesicles 2015, 4, 27066. [CrossRef]

37. Montemurro, N.; Fanelli, G.N.; Scatena, C.; Ortenzi, V.; Pasqualetti, F.; Mazzanti, C.M.; Morganti, R.; Paiar, F.; Naccarato, A.G.; Perrini, P. Surgical outcome and molecular pattern characterization of recurrent glioblastoma multiforme: A single-center retrospective series. Clin. Neurol. Neurosurg. 2021, 207, 106735. [CrossRef]

38. Piryani, S.O.; Jiao, Y.; Kam, A.Y.F.; Liu, Y.; Vo-Dinh, T.; Chen, B.J.; Chao, N.J.; Doan, P.L. Endothelial Cell-Derived Extracellular Vesicles Mitigate Radiation-Induced Hematopoietic Injury. Int. J. Radiat. Oncol. Biol. Phys. 2019, 104, 291-301. [CrossRef]

39. Wen, S.; Dooner, M.; Cheng, Y.; Papa, E.; del Tatto, M.; Pereira, M.; Deng, Y.; Goldberg, L.; Aliotta, J.; Chatterjee, D.; et al. Mesenchymal stromal cell-derived extracellular vesicles rescue radiation damage to murine marrow hematopoietic cells. Leukemia 2016, 30, 2221-2231. [CrossRef]

40. Wang, J.; Cazzato, E.; Ladewig, E.; Frattini, V.; Rosenbloom, D.I.S.; Zairis, S.; Abate, F.; Liu, Z.; Elliott, O.; Shin, Y.-J.; et al. Clonal evolution of glioblastoma under therapy. Nat. Genet. 2016, 48, 768-776. [CrossRef]

41. Al-Nedawi, K.; Meehan, B.; Micallef, J.; Lhotak, V.; May, L.; Guha, A.; Rak, J. Intercellular transfer of the oncogenic receptor EGFRvIII by microvesicles derived from tumour cells. Nat. Cell Biol. 2008, 10, 619-624. [CrossRef] [PubMed] 
42. Hu, Y.; Yan, C.; Mu, L.; Huang, K.; Li, X.; Tao, D.; Wu, Y.; Qin, J. Fibroblast-derived exosomes contribute to chemoresistance through priming cancer stem cells in colorectal cancer. PLoS ONE 2015, 10, e0125625. [CrossRef] [PubMed]

43. Bronisz, A.; Godlewski, J.; Chiocca, E.A. Extracellular Vesicles and MicroRNAs: Their Role in Tumorigenicity and Therapy for Brain Tumors. Cell. Mol. Neurobiol. 2016, 36, 361-376. [CrossRef] [PubMed]

44. Pan, J.; Sheng, S.; Ye, L.; Xu, X.; Ma, Y.; Feng, X.; Qiu, L.; Fan, Z.; Wang, Y.; Xia, X.; et al. Extracellular vesicles derived from glioblastoma promote proliferation and migration of neural progenitor cells via PI3K-Akt pathway. Cell Commun. Signal. 2022, 20, 7. [CrossRef] [PubMed]

45. Dalrymple, S.J.; Parisi, J.E.; Roche, P.C.; Ziesmer, S.C.; Scheithauer, B.W.; Kelly, P.J. Changes in Proliferating Cell Nuclear Antigen Expression in Glioblastoma Multiforme Cells along a Stereotactic Biopsy Trajectory. Neurosurgery 1994, 35, 1036-1045. [CrossRef]

46. Schiffer, D.; Cavalla, P.; Dutto, A.; Borsotti, L. Cell proliferation and invasion in malignant gliomas. Anticancer Res. 1997, 17, 61-69. [PubMed]

47. Giese, A.; Bjerkvig, R.; Berens, M.; Westphal, M. Cost of Migration: Invasion of Malignant Gliomas and Implications for Treatment. J. Clin. Oncol. 2003, 21, 1624-1636. [CrossRef] [PubMed]

48. Garnier, D.; Ratcliffe, E.; Briand, J.; Cartron, P.-F.; Oliver, L.; Vallette, F.M. The Activation of Mesenchymal Stem Cells by Glioblastoma Microvesicles Alters Their Exosomal Secretion of miR-100-5p, miR-9-5p and let-7d-5p. Biomedicines 2022, 10, 112 [CrossRef] [PubMed]

49. Hoshino, D.; Kirkbride, K.C.; Costello, K.; Clark, E.S.; Sinha, S.; Grega-Larson, N.; Tyska, M.J.; Weaver, A.M. Exosome Secretion Is Enhanced by Invadopodia and Drives Invasive Behavior. Cell Rep. 2013, 5, 1159-1168. [CrossRef] [PubMed]

50. Morel, L.; Regan, M.; Higashimori, H.; Ng, S.K.; Esau, C.; Vidensky, S.; Rothstein, J.; Yang, Y. Neuronal exosomal miRNAdependent translational regulation of astroglial glutamate transporter GLT1. J. Biol. Chem. 2013, 288, 7105-7116. [CrossRef]

51. Lessi, F.; Aretini, P.; Rizzo, M.; Morelli, M.; Menicagli, M.; Franceschi, S.; Mazzanti, C.M. Analysis of exosome-derived microRNAs reveals insights of intercellular communication during invasion of breast, prostate and glioblastoma cancer cells. Cell Adhes. Migr. 2021, 15, 180-201. [CrossRef] [PubMed]

52. Yang, Q.; Wei, B.; Peng, C.; Wang, L.; Li, C. Identification of serum exosomal miR-98-5p, miR-183-5p, miR-323-3p and miR-19b-3p as potential biomarkers for glioblastoma patients and investigation of their mechanisms. Curr. Res. Transl. Med. 2022, $70,103315$. [CrossRef]

53. Movahedpour, A.; Khatami, S.H.; Khorsand, M.; Salehi, M.; Savardashtaki, A.; Mirmajidi, S.H.; Negahdari, B.; Khanjani, N.; Naeli, P.; Vakili, O.; et al. Exosomal noncoding RNAs: Key players in glioblastoma drug resistance. Mol. Cell. Biochem. 2021, 476, 4081-4092. [CrossRef] [PubMed]

54. Mukherjee, S.; Pillai, P.P. Current insights on extracellular vesicle-mediated glioblastoma progression: Implications in drug resistance and epithelial-mesenchymal transition. Biochim. Biophys. Acta Gen. Subj. 2021, 1866, 130065. [CrossRef] [PubMed]

55. Cheng, L.; Sharples, R.A.; Scicluna, B.J.; Hill, A.F. Exosomes provide a protective and enriched source of miRNA for biomarker profiling compared to intracellular and cell-free blood. J. Extracell. Vesicles 2014, 3, 23743. [CrossRef]

56. Ma, C.; Nguyen, H.P.T.; Luwor, R.; Stylli, S.S.; Gogos, A.; Paradiso, L.; Kaye, A.H.; Morokoff, A.P. A comprehensive meta-analysis of circulation miRNAs in glioma as potential diagnostic biomarker. PLoS ONE 2018, 13, e0189452. [CrossRef]

57. Morokoff, A.; Jones, J.; Nguyen, H.; Ma, C.; Lasocki, A.; Gaillard, F.; Bennett, I.; Luwor, R.; Stylli, S.; Paradiso, L.; et al. Serum microRNA is a biomarker for post-operative monitoring in glioma. J. Neuro-Oncol. 2020, 149, 391-400. [CrossRef] [PubMed]

58. Atai, N.A.; Balaj, L.; van Veen, H.; Breakefield, X.O.; Jarzyna, P.A.; van Noorden, C.J.; Skog, J.; Maguire, C.A. Heparin blocks transfer of extracellular vesicles between donor and recipient cells. J. Neurooncol. 2013, 115, 343-351. [CrossRef] [PubMed]

59. Thery, C.; Amigorena, S.; Raposo, G.; Clayton, A. Isolation and characterization of exosomes from cell culture supernatants and biological fluids. Curr. Protoc. Cell Biol. 2006, 30, 3-22. [CrossRef] [PubMed]

60. Théry, C.; Witwer, K.W.; Aikawa, E.; Alcaraz, M.J.; Anderson, J.D.; Andriantsitohaina, R.; Antoniou, A.; Arab, T.; Archer, F.; Atkin-Smith, G.K.; et al. Minimal information for studies of extracellular vesicles 2018 (MISEV2018): A position statement of the International Society for Extracellular Vesicles and update of the MISEV2014 guidelines. J. Extracell. Vesicles 2018, 7, 1535750. [CrossRef]

61. Escrevente, C.; Keller, S.; Altevogt, P.; Costa, J. Interaction and uptake of exosomes by ovarian cancer cells. BMC Cancer 2011, 11, 108. [CrossRef]

62. Greening, D.W.; Nguyen, H.P.; Elgass, K.; Simpson, R.J.; Salamonsen, L.A. Human Endometrial Exosomes Contain HormoneSpecific Cargo Modulating Trophoblast Adhesive Capacity: Insights into Endometrial-Embryo Interactions. Biol. Reprod. 2016, 94, 38. [CrossRef] [PubMed]

63. Franken, N.A.P.; Rodermond, H.M.; Stap, J.; Haveman, J.; Van Bree, C. Clonogenic assay of cells in vitro. Nat. Protoc. 2006, 1, 2315-2319. [CrossRef] [PubMed]

64. Stylli, S.S.; I, S.T.; Verhagen, A.M.; Xu, S.S.; Pass, I.; Courtneidge, S.A.; Lock, P. Nck adaptor proteins link Tks5 to invadopodia actin regulation and ECM degradation. J. Cell Sci. 2009, 122, 2727-2740. [CrossRef] [PubMed]

65. Celiku, O.; Johnson, S.; Zhao, S.; Camphausen, K.; Shankavaram, U. Visualizing molecular profiles of glioblastoma with GBM-BioDP. PLoS ONE 2014, 9, e101239. [CrossRef] [PubMed] 